\title{
Notes on the Preservation of Fishing Nets by means of Copper Soaps.
}

\author{
By \\ W. R. G. Atkins, Sc.D., F.R.S., \\ Head of the Department of General Physiology at the Plymouth Laboratory.
}

With 1 Figure in the Text.

Procending on the hypothesis that the deterioration of nets is due mainly to bacterial action and the action of sunlight, some attempts were made to prolong the serviceable life of silk plankton tow-nets and hemp "stramin" young fish trawl-nets by periodical treatment with formalin, which had been neutralised with borax to avoid the injurious action of the acid always present in the commercial product. It was, however, found (1923) that formalin treatment was positively harmful, as was also rinsing out the silk nets with fresh water. It was further shown that sunlight is extremely destructive to silk nets. These should therefore be dried after use and stored in the shade, or given the minimum exposure to sunlight during drying. Sunlight is in fact harmful to all fabrics, and the thinner and more transparent the fabric the greater is the resulting damage.

Valuable results were obtained by Taylor and Wells (1923) using copper oleate dissolved in petrol or benzol as a preservative for nets immersed in salt water. To avoid the creeping out of the soap to the surface on drying, the 10 per cent oleate solution receives 1 per cent of mineral oil or of creosote. In fresh water less satisfactory results were obtained unless a considerable amount of tar was added as a binder.

Since silk tow-nets are costly, about $£ 11$ for a set of four, and become considerably weakened in about three months, varying according to the amount of wear, trials were made first on fine and coarse tow-net silk. Silk netting treated with 10 per cent copper oleate was kept in sea-water for five months, the water being changed every other day, and though in two or three months all noticeable signs of the soap had vanished the netting remained sound. In about seven months the fine mesh (100 to the inch) netting had become much weakened, and the coar e mesh (26 to the inch) had also deteriorated, though still good enough to use as a net. Controls were much weakened inside five weeks and shortly after that could be torn like wet paper. 
Owing to the favourable results obtained all silk nets taken into use by the Marine Biological Association or issued to other institutions have been treated with copper oleate or with a mixed copper soap specially prepared by Messrs. Lever Bros. This, being less soluble than oleate, was used in 5 per cent solution in petrol, which is, however, far from being a saturated solution in warm weather. When tried on stout stramin (hemp) netting good results were obtained, but less striking, for this material is vastly more resistant than silk. It may be added that the fine mesh silk is clogged by a film of soap after treatment, but when towed in the water this soon comes away. Particles of the green copper soap may be found in the tow-nettings for several days.

Stout stramin netting was placed in three jars, with sea-water from the aquarium tanks, which was changed three times a week and examined at intervals. They contained respectively an untreated control, a piece treated with 10 per cent oleate and one treated with 5 per cent mixed soaps.

The behaviour of the stramin and silk nets is shown in the accompanying figure. The serviceable life of the net is considered to be at an end when it is possible to tear it by hand, using considerable effort. This occurs about one month after the time when single threads can be broken by hand.

It may be pointed out that the soaps dissolve only when the nets are in water, but bacterial action goes on as long as the net is damp, so the immersion tests are in this respect unduly severe on the preservative as regards its use on seine nets, though not severe enough as regards pound nets, which are not only continuously immersed, but are also subjected to the action of currents of water.

Light linen and cotton fabrics were exposed in an horizontal position upon the flat roof of the Laboratory, being mounted on wooden frames after treatment with oleate or mixed copper soaps. After exposure for two very rainy months much of the soap on the outer sides was washed away, though after twelve months the stoutest of the cottons still retained a large amount of soap on the under surface, the mixed soap being retained considerably better than the pure oleate. This indicates that the action of rain upon nets heaped on the deck or hung up to dry may be far more rapid in removing copper soap than is that of sea-water. Cotton nets, however, retain the soap far better than stramin.

\section{Use of Binding Agents with Copper Soap.}

Taylor and Wells found that the addition of a certain proportion of tar was advantageous in binding the soaps more firmly, and for heavy gear such mixtures are probably very useful. Following the receipt of further information from the U.S. Dept. of Fisheries, through Messrs. 


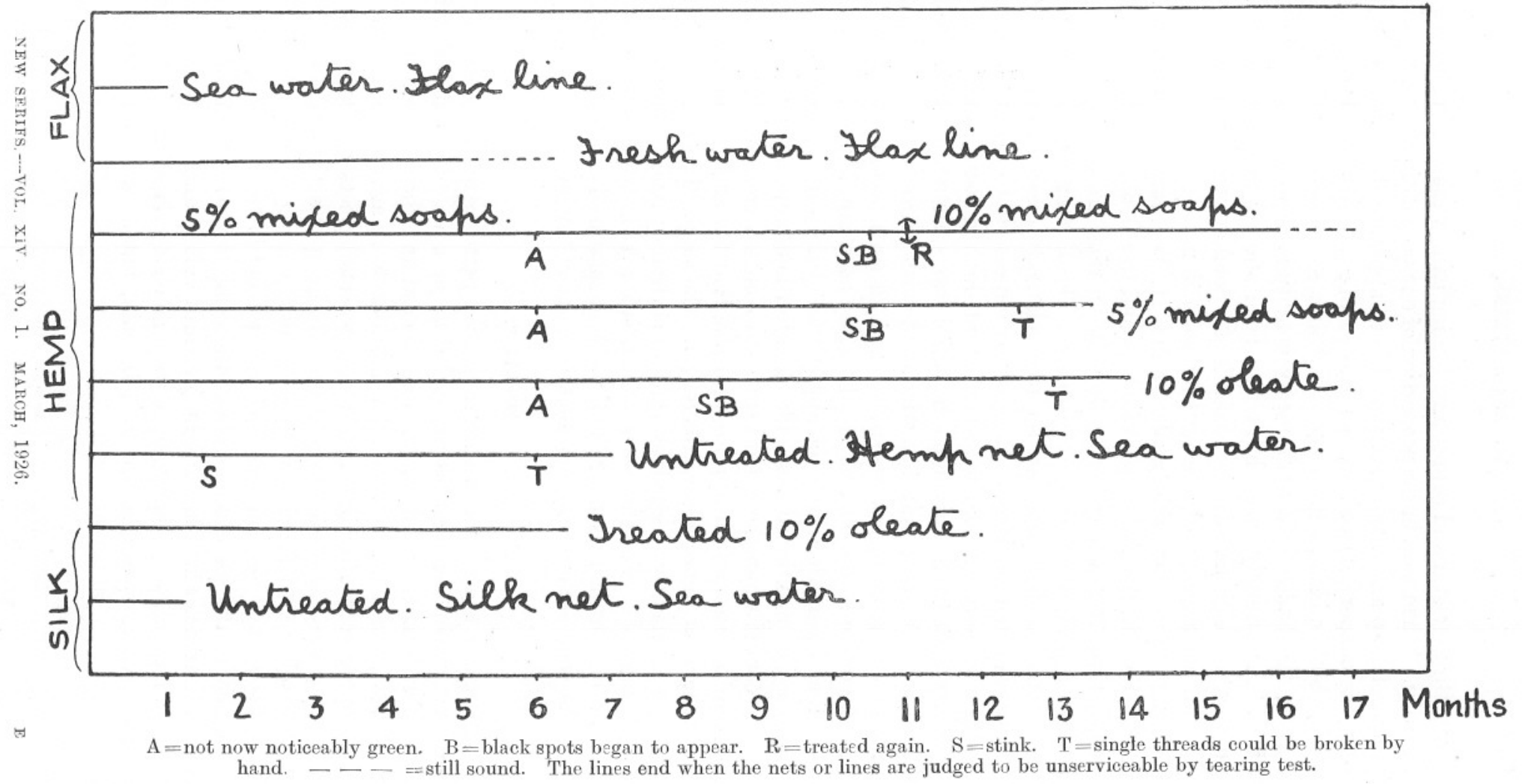


Lever Brothers, tar and copper anti-fouling paint were tried as binders for the soap. When used in the proportion of one pound of paint or tar to one pound of soap and a gallon of petrol both appear to be far more durable than the copper soaps alone, as far as can be judged from three months' trial; both mixtures have the disadvantage-possibly only initial-of leaving the hands in a very messy condition, especially the one with paint. Accordingly trials have also been started using one-half, onequarter, one-eighth and one-sixteenth of a pound of paint to one of soap; all dilutions appear to be better than soap alone.

Acting on a suggestion made by $\mathrm{Mr}$. H. W. Harvey resin was also tried. Used in the proportion of one pound to one of soap, to a gallon of petrol, three months' immersion has shown that the addition of resin is a great improvement over soap alone. The netting dries readily after treatment and handling the net is a relatively clean business - a very important point for users. It is as yet impossible to say whether resin mixture is more durable than tar or anti-fouling paint mixtures. The difficulty that resin is insoluble in petrol was surmounted by melting it with the copper soap and then stirring up with petrol, when it was found to give a mixture of low viscosity which in time becomes thicker. For this the writer is indebted to his laboratory assistant, Mr. F. E. Radcliffe, as well as for much help in the application of the various preservatives.

It may be mentioned that silk plankton nets appear to be more uniformly coated when the 5 per cent soap solution contains also one-half per cent of resin, and it appears probable that the small amount of resin will somewhat improve the adherence of the soap. The finest mesh silk is not permanently clogged by this proportion of resin, though it is by larger amounts. For the coarser mesh silk nets it is permissible to use more resin, but at present the half per cent mixture has been substituted here for soap alone in the routine treatment of tow-nets.

\section{Solvent.}

As regards the solvent used, commercial petrol is quite satisfactory in summer, when the temperature is $15^{\circ} \mathrm{C}$. or over. In colder weather, $10^{\circ} \mathrm{C}$. or less, more difficulty is experienced and the soap solution soon becomes gelatinous. Under all conditions it is advantageous to melt the copper soap after breaking it up into small pieces by immersing the tin in hot water and then to remove it to the open air and to add a little of the solvent to it with stirring, finally pouring it into the solvent. "Water white" benzene was tried as a solvent instead of petrol, but the solubility of the soaps seems about the same in both. Commercial gasworks benzene, which has a light brownish colour and a very noticeable odour of pyridine, is, however, a very much better solvent. It is also cheaper where it can be obtained in bulk, but as it is not universally 
obtainable in readily handled quantities, as is petrol, cost of carriage and of drums add considerably to the expense, so that it may become less economical than petrol. For any large scale treatment of nets it is, however, quite the best solvent. Solvent naphtha is more expensive and does not dissolve the soaps so readily.

\section{Treatment and its Cost.}

It may be mentioned the herring nets treated with copper soaps gave trouble when taken into use by the meshes slipping. In the usual treatment with cutch the nets shrink, so the knots tighten up, whereas in the soap treatment there is no shrinking. It is, however, customary in this district to pull new nets by hand to tighten up the knots before treating with cutch or creosote, and it seems advisable that such nets should be thus tightened up before treatment with copper soap.

As regards the cost of this treatment, for a 35-lb. herring net about seven gallons of the mixture is required, thus for :

\section{$10 \%$ benzol solution.}

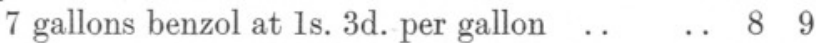

6 lbs. copper soap at, say, 9 d. per lb. $\quad$.. $\quad \ldots \quad 4 \quad 6$

$\begin{array}{cc}\overline{13} & 3\end{array}$

$5 \%$ benzol solution, deduct 3 lbs. of soap $\quad \ldots \quad 2 \quad 3$

110

Using kerosene (paraffin oil) at 9d. per gallon the cost would be $7 \mathrm{~s} .6 \mathrm{~d}$. Where petrol has to be used the cost of solvent is greater, 1s. 6d. to 1s. 9d. per gallon. In any case the cost of the solvent is far greater than that of the soap, so that evaporation losses should be minimised. No estimate has been included for the cost of labour in handling the nets. The treatment can be carried out by anybody, and a pound of soap to a gallon of solvent is a convenient formula, which gives about a 12 per cent solution. One pound of mineral lubricating oil is added to ten of soap.

\section{Fishing-LINES.}

Some tests have been carried out upon lines such as used for rod fishing in fresh water mainly, but the results are being held over as nothing very definite has been obtained, owing it seems to the poor adherence of the copper soaps to their highly glossy surface. It may be mentioned, however, that a pure flax line remained sound in a soft fresh water for five months, and is still sound, whereas it became absolutely 
rotten in sea-water in one month in summer and in less than two in cooler weather.

Further trials are in progress upon the effect of tar, Japan black, antifouling paint and resin as binders to improve the adherence of the soap to the lines and nets.

\section{Preparation of Soap Mixture for issue in Liquid Form to be used with Paraffin Oil.}

There are obvious advantages to the user if the soap can be obtained in liquid form so that it does not need melting to dissolve in cold weather. Paraffin is also much less inflammable than petrol or benzol, and already has a good name among fishermen, as it is used in washing down newly built boats as a preservative for the wood. It was suggested by Mr. H. W. Harvey that an attempt should be made to produce a soap mixture which would only have to be poured into the paraffin. Among the possible liquids in which the soaps and resin might be brought into solution readily, tetrachlorethane was ruled out on account of its poisonous properties, also methylethyl ketone, butyl alcohol, and turpentine on account of their cost. Carbon tetrachloride appears to be both cheap and suitable. It has also the advantage that it is non-inflammable, being, in fact, the principal constituent of a fire extinguisher for combating oil fires. A pound of copper soap (as supplied ready mixed with one-tenth its weight of mineral oil) is melted and a pound of powdered resin is stirred in - or a pound of tar may be used instead. To the mixture a pound and a half of carbon tetrachloride is added. The result is a mobile solution which becomes thicker when cold. This can be poured into paraffin oil to give roughly a 12 per cent soap solution, using three and a half pounds of the mixture to a gallon of paraffin oil, which weighs about eight and a half pounds and is much cheaper than petrol. A very useful 5-6 per cent solution may be prepared, using half the amount of soap mixture. In the proportions mentioned a mixture allowed to stand in the open on a cold night becomes gelatinous, but in a warm room it becomes liquid again. Being non-inflammable there is no risk of fire, but it should be remembered that carbon tetrachloride is volatile and gives off a very heavy vapour similar to chloroform in its action when inhaled. Pieces of stramin thus treated have been placed in sea-water for a durability test, but as carbon tetrachloride is volatile and Taylor and Wells found paraffin satisfactory where its solvent action was sufficiently good, viz. where it was not desired to mix it with a large volume of tar, it seems that no trouble need be anticipated on this score. We find the adherence is inferior with paraffin. 


\section{SUMMARY.}

The use of a mixture of copper soap, 5 or 10 per cent, with 1 per cent mineral oil, dissolved in petrol or benzol, increases the life of silk plankton nets by about four or five hundred per cent, and roughly doubles that of a hemp net for a single treatment. The beneficial effects last far longer than does the green colour. Re-treatment at suitable intervals is recommended.

The use of 5 or 10 per cent of resin * with an equal percentage of the soap improves its adherence to the fabric, as does also the addition of tar or anti-fouling paint. For silk nets, to avoid clogging, only one-half per cent of resin should be used with 5 per cent of soap.

A liquid soap mixture, which may be used with paraffin oil, can be obtained by adding one pound of resin to one pound of melted copper soap, and then dissolving in one and a half pounds of carbon tetrachloride. When wanted, this is used to make up a paraffin oil soap solution of the desired concentration, but adherence is less than with petrol.

\section{REFERENCES.}

Atkins, W. R. G. " Factors Affecting the Durability of Silk Plankton Tow-nets and Young Fish Trawl-nets." Journ. Mar. Biol. Assoc., 1923, 13, 276-281.

Fillon, R. "Les traitements préservateurs des filets de pêche en coton. Office sci. et tech. des pêches maritimes. Notes et mém." No. 45. Paris, Oct., 1925, p. 39.

Taylor, H. F., and Wells, A. W. "Properties and Values of Certain Fish Net Preservatives." U.S.A. Bureau of Fisheries Document, No. $947,1923$.

\section{NOTE.}

When the foregoing paper was almost completed M. Fillon's valuable memoir came to hand. It contains a comparison of results obtained with copper oleate, and with various methods of tanning; it also describes the new method of treatment, with rubber latex, devised by Dr. J. Olie of Utrecht. A treatment with boiling cutch solution (from Acacia catechu) followed by the application of ammoniacal copper sulphate, the process being then repeated, was found to be superior to treatment with copper oleate solution in benzol mixed with an equal volume of coal-tar. A previous treatment with cutch brought the latter method nearly up to the level of the ammoniacal copper fixation, the details of which were carried out according to Dr. Olie's instructions.

\footnotetext{
* Tensile tests on strands of stramin after four months' immersion show that resin
} does not improve the soap mixture, though it is retained better than the soaps alone. 
